\title{
Potato Seed Supply, Marketing and Production Constraints in Eritrea
}

\author{
Biniam Mesfin Ghebreslassie1, S. Mwangi Githiri², Tadesse Mehari'1, Remmy W. Kasili \\ ${ }^{1}$ Department of Horticulture, Hamelmalo Agricultural College, Keren, Eritrea \\ ${ }^{2}$ Department of Horticulture, Jomo Kenyatta University of Agriculture and Technology, Nairobi, Kenya \\ ${ }^{3}$ Institute of Biotechnology Research, Jomo Kenyatta University of Agriculture and Technology, Nairobi, Kenya \\ Email: bm95913@yahoo.com
}

Received 28 September 2014; revised 27 October 2014; accepted 15 November 2014

Copyright (C) 2014 by authors and Scientific Research Publishing Inc.

This work is licensed under the Creative Commons Attribution International License (CC BY).

http://creativecommons.org/licenses/by/4.0/

(c) (i) Open Access

\begin{abstract}
Potato is an important vegetable crop in Eritrea contributing significantly to food security. Despite its importance, however, production and thus supply of the crop in the market are limited. The current study is designed to understand the seed supply system, marketing out lets and major production constraints. The survey was conducted in the two main potato producing Zobas of the country (Zoba Maekel and Zoba Debub). Qualitative and quantitative data was generated using focus group discussion (PRA) and semi structured questionnaire, respectively. A total of 20 villages were visited and 138 farmers were interviewed. The finding revealed that there is no standard seed supply system thus majority $(\mathbf{9 1 . 3 \%})$ of the growers purchase seed from open market with a limited supply from the Ministry of Agriculture. Furthermore, about $63 \%$ of the farmers from Zoba Maekel reserve their own seed for the next cycle compared to $53.6 \%$ from Zoba Debub. It was noted that the Tsaeda embaba variety grows predominantly in the country owing to its yield and resistance. Majority of the growers rely on tuber colour and shape for variety identification, thus over $76 \%$ prefer the round shaped and white coloured variety. The potential marketing outlets include wholesale, retailer and direct to consumers. Majority (78.3\%) of the interviewed growers indicated that large portion of their produce is marketed via wholesaler followed by retailers $(27.5 \%)$. Main production limiting constraints are identified as low input supplies, availability and cost of clean seeds, pest pressure while huge market demand and access to transportation are considered as potentials encouraging grower. It is, therefore, recommended that an immediate action to establish sustainable seed supply system is taken into consideration in line with a regular extension service to provide technical advice to growers.
\end{abstract}

\section{Keywords}

Potato, Seed Source, Marketing, Constraints, Potentials 


\section{Introduction}

Potato (Solanumtuberosum L.) is the fourth most important food crop in the world, after wheat, maize, and rice ([1] [2]). The crop plays a significant role in human nutrition worldwide, where more than 320 million tones of potatoes are produced annually on 20 million hectares of land ([3] [4]). It is also worth mentioning that it is number one non cereal crop [5]. The importance of potato in developing countries could be attributed to two main reasons: Firstly, that potato crop produces more edible energy and protein per unit area and time than other food crops, and secondly, that potato fits well into multiple cropping systems prevalent in tropical and subtropical agro-climatic conditions ([6] [7]). According to [4] although the crop was considered as a subsistence crop in many developing and Least Developed Countries until recently, its market is expanding rapidly today as a result of urbanization. This is further supported by [8] indicating that potato area in Sub Saharan African countries has grown as a result of increasingly emerging market oriented farmers in response to huge demand from growing urban markets. Moreover, because of its bulky in nature, it does not normally enter into international trade unlike major cereals. Only a fraction of its total production enters foreign trade [7]. Majority of it is consumed locally and/or oriented to domestic markets, thus its price is predominantly determined by local prices with limited influence from foreign trades [5]. The crop serves as a buffer to rising food prices, especially cereals [8]. It is, thus, termed as a small holder and emergency crop, especially in developing countries. This growing domestic market presents a valuable opportunity for smallholder farmers [4] besides benefiting vulnerable low income consumers.

Likewise, it is one of the most important and widely grown vegetable crops in Eritrea. The crop contributes to food security either directly as a food source and/or as a cash crop. The country has a long history of growing potato. The bulk of production occurs in the central highlands (Zoba Maekel and Zoba Debub) with a limited amount coming from Zoba Anseba and Zoba Semenawi Keyh Bahri. Potato cultivation is predominantly by smallholder farmers with traditional systems of low input low output scheme. Estimates by the Ministry of Agriculture (MoA) 2011 indicated that the total land area under potato cultivation is 24,086 ha with an average yield of 11 ton/ha. The country has no stablished quality seed supply system. Thus, the Ministry of Agriculture in colaboration with various partners import seed potato from abroad, but the amount is of limited not pacing up with the huge demand from the growers. This shortage of available clean planting material has led to low yield, disease spread and low quality produce. Similarly, the marketing system is informal between farmer to farmer and/or farmer to wholesalers and with limited degree between growers and consumers. According to [7] it was mentioned that in the poorest countries, potatoes marketing is practiced with low coordination and lack of information through fragmented leading to high supply risks and high transactions costs.

The current study is designed to investigate the potato seed source scheme, varieties used, produce transportation and marketing systems in Eritrea. The study further tried to identify major constraints that hinder potato productivity. The findings will offer the possibility to respond to the multiple and complex constraints affecting potato productivity in Eritrea.

\section{Materials and Methods}

\subsection{Site Description}

The survey was conducted in the two major potato producing Zobas (regions) of Eritrea (Zoba Maekel, and Zoba Debub). Zoba Maekel, the smallest of the six Zobas of Eritrea, is located in the center of the country. Zoba Debub is located along a portion of the national border with Ethiopia. It is the largest region in the country by population. The two Zobas were selected purposely because of their importance and coverage in potato growing.

\subsection{Study and Sampling Design}

The survey consists of qualitative, using participatory rural appraisal (PRA) approach, and quantitative, using semi-structured questionnaire, data collection. Data collection took place between 15 and 29 November, 2013. Trained enumerators were involved to interview and collect relevant information from farmers in the field. The role of the trained enumerators was to understand and interpret farmers' word scientifically, especially in the area of variety identification, disease and pest types etc. In both Zobas, a stratified sampling system was used followed by random selection of Sub-Zobas and villages. The design was developed in consultation with experts from the MoA in each Zoba. Accordingly, more than 20 villages from each Zoba comprising 138 farmers in to- 
tal were identified and interviewed. For the focus group discussion, representative of farmers comprising men and women from each Zoba separately participated.

\subsection{Data Analysis}

Qualitative and quantitative raw data collected from the diagnostic survey were analysed to draw and generate useful information for documentation and to serve as useful reference for scientific community and policy makers. Quantitative data from the survey were subjected to a statistical analysis using SPSS for computational analysis after which results were expressed in the form of means (averages), and percentages.

\section{Results and Discussions}

\subsection{Potato Seed Supply}

Good quality seed is very important factor to optimize productivity. Availability of quality and certified potato seeds is the major constraint across all the visited locations. There is no standard seed supply and distribution system in the country. It was also reported by [9] and [10] that in the three neighboring countries (Kenya, Uganda and Ethiopia) the seed potato system is characterized by a limited availability and limited use of commercially traded high quality seed potato. Yet, the major constraint of potato production in the Asia and Pacific region is the inadequate supply of reasonably priced, farmer-preferred, quality seeds [11]. It was rated earlier that although, the low potato productivity in most developing countries is attributed to a number of factors, quality seed is probably the most important factor, as it accounts for 40 - 50 percent of the total cost of production [12].

\subsubsection{Seed Sources}

Ever since the inception of the country, it remained to be the mandate and responsibility of the MoA to import and distribute certified seeds to growers. The Ministry has imported certified seeds from abroad several times in collaboration with various partners. The farmers during the focus group discussion put forward their reservation and concern that the amount of imported seeds by the MoA is not only insufficient, but also they claim that there is unfair distribution. The Ministry, however, indicated that it has set up criteria for distribution, which include size of land, water availability, resource availability, experience and willingness to grow potato. Nonetheless, this acute shortage of standard seed has led to illegal importation of seeds from neighbouring countries by various traders either licensed or otherwise. A similar phenomenon was reported for farmers in Kenya [13] and in the Eastern Africa region [9] mostly plant seeds from informal sources such as farm-saved (self-supply), local markets or neighbours, because of shortage of clean planting materials. Most of the seed available in developing countries is from informal sources, which means the quality of the seed is not guaranteed [12]. Although the illegal importation in Eritrea, has contributed immensely to ease the problem it, however, created unnecessary duplication of varieties and become a main source of confusion because the varieties and their status is unknown. Unless an immediate action is taken to control the free movement of seeds, the situation is going to get worse. More importantly, since potato is largely propagated by tubers, there is a great risk of introducing alien pathogens or pests ([11], [12]). On the other hand, termination of the government subsidized certified seed distribution in parts of India, resulted in abrupt decrease of area under cultivation [14].

It is not surprising, thus, majority of the respondents replied that they obtain their seeds from unknown market sources. It's shown in Figure 1 that about 91.3\% of the respondents purchase seed from the market in addition to reserving their own seed from previous harvest and/or obtain from the MoA. [15] reported that a wide variety of potato seeds are planted and farmers replant the same seeds repeatedly for about five years, although most (72\%) buy some new seed each year in Ecuador. Similarly, farmers in Kenya, Uganda and Ethiopia did renew their seeds after 6, 7 and 3 seasons, respectively [10]. This acute shortage of clean seed is most common in all the Sub Saharan Africa countries including Eritrea which is becoming an important limiting factor for potato optimization [8].

The current finding further revealed that about $63 \%$ of the growers in Zoba Maekel reserve their own seeds for the next generation as compared to $53.6 \%$ from Zoba Debub. The figure confirms the previous finding (data not shown here) that majority of growers in Zoba Maekel use the old landraces hence use their own seeds since the varieties are no longer available in the market. The farmers indicated during the PRA discussion that sharing of potato seed with friends is not a common practice among potato growers in the two Zobas. But if it happens, 


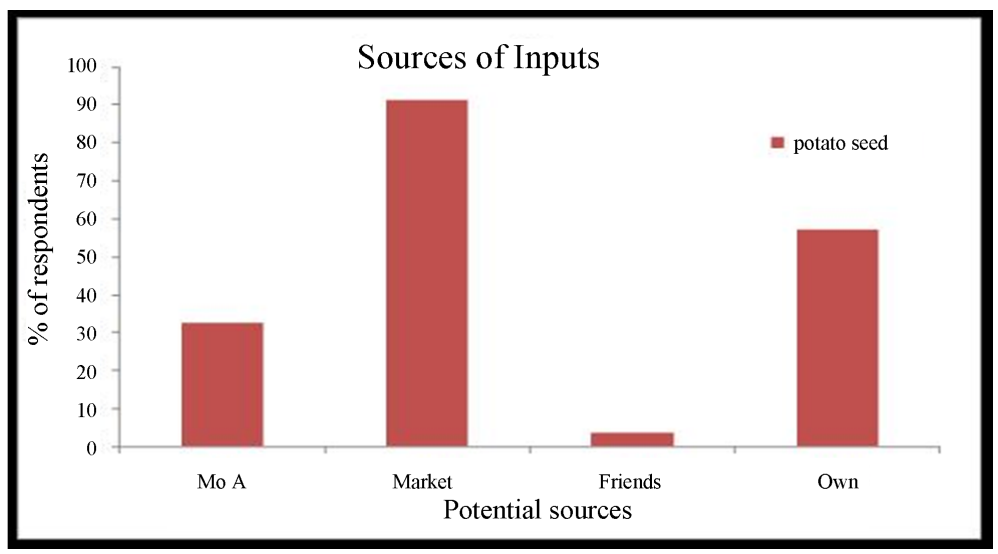

Figure 1. Main sources of potato cultivation inputs (potato seeds).

they do it in kind not in cash. The most important source of seed potato in Kenya is neighbours, while in Uganda and Ethiopia the village market was the dominant source [10]. Although the landraces were highly preferred by the growers owing to their adaptability and market preference, but since they were used frequently without being renewed, their potential is highly degraded from time to time. Unless a renewal and preservation scheme is introduced, therefore, their availability will only be short lived.

\subsubsection{Varieties Grown}

As part of the current survey, identification and preference of potato varieties by the growers and their estimated time of introduction to the area was assessed. Some of the widely grown potato varieties in the country include: Carneshim, Tsaeda embaba, Keih embaba, Shashemanie, Ajiba, Cosmos, Spunta, Zafira, Picaso, Desirée, Kondore, and Grandinaine (Figure 2). Some of these genotypes may not be available currently and/or are localized to a specific area and with a handful of farmers. Majority of the respondents mentioned that they are very much familiar with Tsaeda embaba landrace followed by Ajiba and Spunta (Figure 2). For unknown reasons almost all the respondents prefer a variety with a white flower colour such as Tsaeda embaba and Ajiba. They believe that a white flowered variety is resistant to various stresses and is also high yielding compared to other variety. On the other hand very few know anything about Grandinaine, Kondore and Desirée varieties. The Kondore and Desirée, for instance, were varieties imported from abroad but were only distributed to few localities because of their limited amount.

The survey further attempted to understand how long the varieties have been grown and which ones are preferred from the growers point of view. Accordingly, it was mentioned by the respondents that most of the existing varieties are recently introduced during the last 10 years. The imported varieties, according to the growers, have some advantages like early maturing; high yielding (in their first arrival) and are marketable thus highly preferred by growers, especially by the semi-commercial ones. In addition, the erratic and usually short rainy season only indulges for early maturing varieties to reach full maturity. This trend of seeking for imported and new varieties by the growers (mainly the semi-commercial ones) is exacerbating the rapid disappearance of the old landraces from the field. Over time some potato cultivars have been rejected and replaced by others in Kenya; low yield and susceptibility to diseases were cited as the major weaknesses [13]. Nonetheless, most of the growers rank the following parameters to select a variety according to their priority: yield, maturity time, marketability, resistance and taste. Moreover, farmers may select varieties which correspond best with their conditions of farming and on the basis of their interest.

\subsection{Variety Preference}

\subsubsection{Maturity Time}

Maturity time of the varieties grown varies between three to four months. Most of the recently imported genotypes are early maturing with a maximum of 90 days after planting (DAP). Whereas the old varieties or land races are late maturing taking up to 120 DAP to mature. As previously mentioned, farmers in Zoba Maekel grow mainly the landrace potato genotypes, which are late maturing. Findings of the current survey, hence, conform 


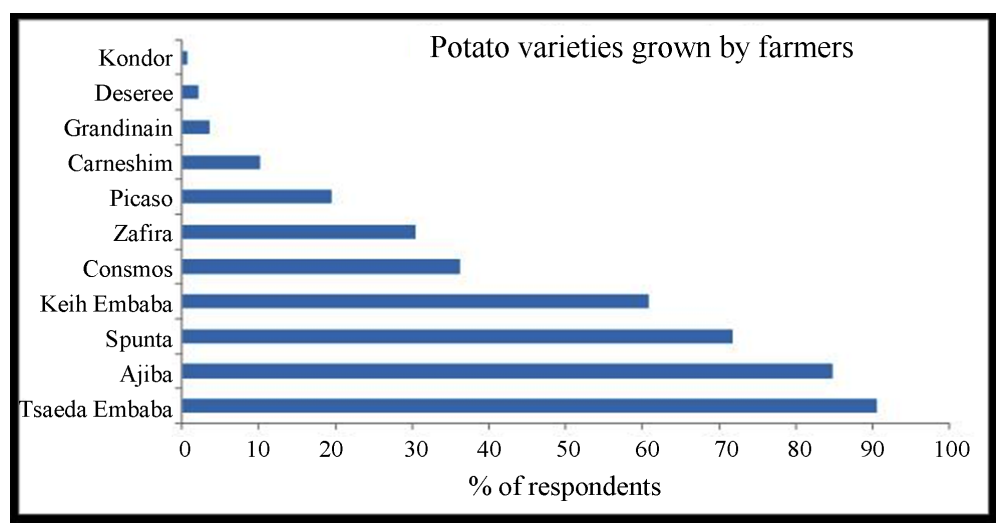

Figure 2. Ranking of major potato varieties grown by farmers.

to the above statement where $24.1 \%$ and $4.8 \%$ of the respondents from Zoba Maekel and Zoba Debub, respectively grow late maturing along with early maturing genotypes (Table 1). The semi commercial and market oriented growers in Zoba Debub use mainly the imported early maturing varieties to get early return for their investment. The same occurrence was reported by [13] where early maturity is considered as important for food security for enabling growers generate income early to meet their financial obligations. It is also an important trait in potato growing areas with a high demand for land as early harvesting allows more crop cycles within a year. Maturity time, lower yield and short rainy season are the main reasons for the rapid disappearance of the old varieties from the farm.

\subsubsection{Tuber Shape and Colour}

Growers depend on tuber shape, tuber and flower colour and leaf shape for variety identification. Over $76 \%$ of the growers preferred the round shaped and white coloured potato tubers which includes Ajiba and Zafira. Yet about $16 \%$ mentioned that they prefer the oval shaped and white coloured tubers which include Spunta and Cosmos to mention some (Table 2). The yellow coloured variety, which is preferred by Zoba Maekel growers, is mainly the old land race Carneshim, one which is only common in this Zoba. Some of the reasons for their preference are ranked as market, yield, resistance, taste and earliness, in that order. The choice and order is more or less the same across the two Zobas with a slight difference. In a previous study in Kenya, variety preference by farmers is attributed to high yield potential, late blight resistance, taste, maturity period, market demand, bacterial wilt resistance, tuber size, and drought tolerance [2]. Yet, others base their selection on tuber quality characteristics as per the consumers' interest. The current study revealed that consumers' prefer varieties of round shaped and white coloured tubers followed by oval shaped and white coloured. According to [16]) most consumers decide their preference based on variety, taste, cooking type, outside colour and appearance, while convenience and inside colour are less important.

\subsection{Potential Marketing Outlets}

In Eritrea, potato grows mainly by small scale farmers as food and cash crop. Reports from the neighboring country, Ethiopia indicated that potato is one of the most important sources of on-farm incomes for the farmers ([17] [18]). Especially, in highly accessible areas in terms of market infrastructure, potato becomes important cash crop. The crop's potential not only contributes to food security, but also provides opportunities for rural economic development as cash crop [10]. Majority of the interviewed farmers, especially the subsistent farmers, confirmed that they sort out the harvested crop into three grades depending on what they are used for as seed, tubers for home consumption and marketable ones. The small size tubers are consumed at home, middle sized ones are kept as seed for the next cycle and the rest destined to the market places. Farmers in India, for instance, select small size tubers from the bulk produce for seed [14]. Kenyan farmers on the other hand sell smaller proportion as seed potato, but keep more seed potatoes for their own production than the farmers in Uganda and Ethiopia [18].

The farmers interviewed in this study use a variety of potential outlets, indicating that they are highly market oriented although few farmers who produce for home consumption are included as well. The selected farmers 
Table 1. Varieties used according to their maturity time in the two Zobas.

\begin{tabular}{ccc}
\hline & \multicolumn{3}{c}{ Maturity time of varieties grown } \\
\cline { 2 - 3 } Zoba & $\mathbf{3}$ Months & 4 Months \\
\hline Maekel & $75.9 \%$ & $24.1 \%$ \\
Debub & $95.2 \%$ & $4.8 \%$ \\
Percentage & $87.7 \%$ & $12.3 \%$ \\
\hline
\end{tabular}

Table 2. Preferred potato tuber shape and colour by growers in the two Zobas.

\begin{tabular}{|c|c|c|c|c|c|c|}
\hline \multirow{2}{*}{ Zoba } & \multicolumn{5}{|c|}{ Preferred tuber shape and colour } & \multirow{2}{*}{ Percentage } \\
\hline & Round white & Round yellow & Oval white & Oval yellow & Oval red & \\
\hline Maekel & $57.4 \%$ & $11.1 \%$ & $22.2 \%$ & $3.7 \%$ & $5.6 \%$ & 100 \\
\hline Debub & $88.1 \%$ & $0.0 \%$ & $11.9 \%$ & $0.0 \%$ & $0.0 \%$ & 100 \\
\hline Percentage & $76.1 \%$ & $4.3 \%$ & $15.9 \%$ & $1.4 \%$ & $2.2 \%$ & 100 \\
\hline
\end{tabular}

tend to market a large proportion via wholesalers (78.3\%) and/or retailers (27.5\%). Very few of them also entertain on road side and farm gate selling direclty to consumers (18.8\%). This figure can further be elaborated at Zoba level. From this analysis it was revealed that $95.2 \%$ of the farmers in Zoba Debub and $51.9 \%$ in Zoba Maekel use the wholesale marketing outlet (Figure 3). Very few of the growers use the retailer and/or direct to consumers marketing channel in Zoba Debub. This is because majority of the growers in this Zoba are semi-commercial, thus, likely to make deals with wholesalers than otherwise. On the other hand, a very significant number of growers in Zoba Maekel transport and sell their products themselves directly in the market place. Consequently, $59.3 \%$ and $46.3 \%$ sell their products to retailers and directly to consumers in the market place, respectively. This mode of marketing is almost insignificant in Zoba Debub growers. All the farmers are fully aware that potatoes grown during the off-season and sold directly to ultimate consumers fetch premium price. But this is not commonly practiced thus the farmers always became prime victim of the middle men brokers. Prices for produces by the growers are dictated by the season of production and the distance for delivery in most West African growers [19]. It was mentioned by [7], that owing to institutional constraints, farmers in developing countries typically are not innovative when it comes to marketing their products.

\subsection{Produce Transportation}

Most of the interviewed farmers transport their products to the destination using their own transportation means (motor or animal draft) and/or hiring extra transportation when required. Majority (47.8\%) use own followed by hired (37.7\%) transport systems. Some of them still use public mode of transportation, especialy in Zoba Maekel (Table 3). The table further shows that significant number of growers from Zoba Maekel use animal drfat for transportation. In Ethiopia most ware potato farmers took their produce to village markets, often on horseback or hand carried, where it was sold to wholesalers [10]. It was mentined by [19] that transportation of produce is managed by traders or collective organizations in West African growers. Comparatively the marketing sytem in Eritrea and Ethiopia is traditional than in Kenya and Uganda where they have better developed marketing system. On average the growers in the visited farms transport to a distance of $15 \mathrm{Km}$ ranging from 0 (farm gate) to $88 \mathrm{~km}$ from their farm to the final destination. The distance and mode of transportation varies across the two Zobas. The minimum and maximum marketing distance in Zoba Maekel is $0 \mathrm{Km}$ and $31 \mathrm{Km}$, respectively. This is the the smallest Zoba with an average radius of $30 \mathrm{Km}$ and their main market is the capital Asmara, whereas in Zoba Debub the minimum and maximum distance is 6 and $88 \mathrm{Km}$, respectively. For some of the growers the capital Asmara remained to be their main market place, especially the semi-commercial growers. This is only because the potential buyers are located in the capital and it is worth transporting all the way to the capital to fetch premium prices. 


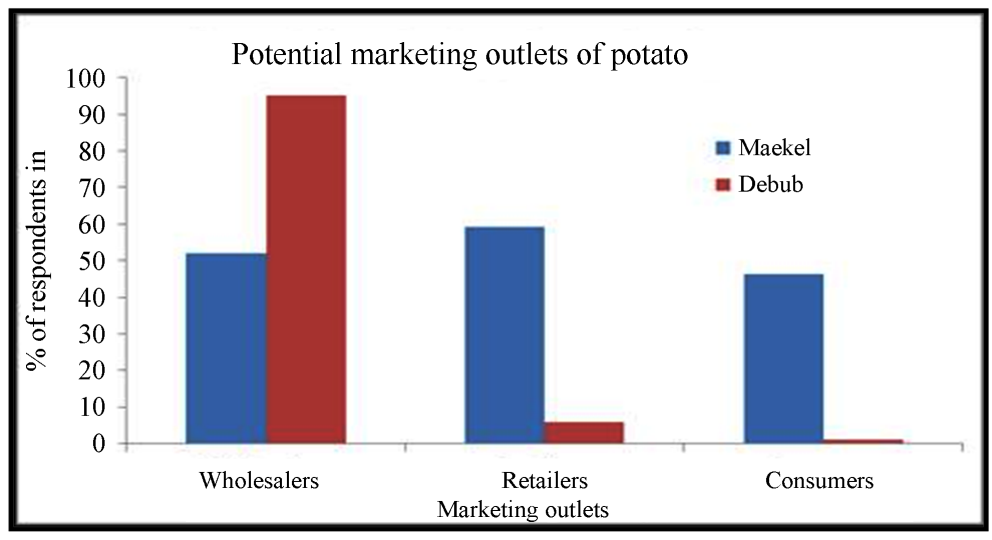

Figure 3. Potential marketing outlets of potato crop.

Table 3. Potato transportation options.

\begin{tabular}{ccccc}
\hline & \multicolumn{4}{c}{ Mode of Transportation } \\
\hline Zoba & Public (\%) & Own (\%) & Hired (\%) & Animal Draft (\%) \\
\hline Maekel & 27.8 & 44.4 & 27.8 & 20.4 \\
Debub & 13.1 & 50 & 44 & 8.3 \\
\hline
\end{tabular}

\subsection{Mode of Consumption}

To date, there is no potato processing plant for chips, fries and the likes in Eritrea. Thus, the harvested potato crops for home consumption are served cooked with limited amount as boiled and/or as salad. It is probably because of this reason that the crop remained a common staple food prepared in avariety of forms in Eritrean dishes. It was reported by [8] [18] that potato is a common menu for most of the population, consumed in different ways in the East African region. Compared with other staple crops in the region, potato has gained importance in the last 20 years [9]. But the mode of consumption varies from country to country. In Eritrea and Ethiopia, for instance, consumption is in the form of sauce in mixture with other spices, whereas consumption of boiled potato is most dominant cultural dish in the rest of the countries in the region [18]. This is of essence, as the first crop that can be harvested after the onset of the rainy season is potato, especially, in rainfed systems. In situations of food insecurity, this makes potato an important 'hunger breaking' crop to assure staple food before grains can be harvested ([10] [12]).

\subsection{Constraints and Potentials}

The current survey revealed that lack of agricultural inputs such as pesticides, fertilizers, application equipments followed by availability and cost of quality seeds are considered to be the main bottlenecks. This remained to be a common problem discouraging more than $97 \%$ of the respondents. On the other hand, availability and easy transportation access followed by availability of water and market are considered potentials that encourage growers. For further in depth realization of the situation across the Zobas see Figure 4 and Figure 5. The slight variation in ranking of constraints and potentials in the two Zobas is attributed to their farming system and scale of cultivation. An essential point of discussion observed during the survey was the relative low weed pressure across all the visited areas.

Moreover, it was noted from the indepth analysis of the study that farmers from Zoba Maekel have potential market, transportation and labour availability thus encouraging them to further expand their productivity (Figure 4). While, growers from Zoba Debub consider easy transportation access and water availability followed by marketing as their encouraging potentials (Figure 5).

\section{Conclusion}

The current study yielded a number of useful information that requires short term and long term intervention. It 


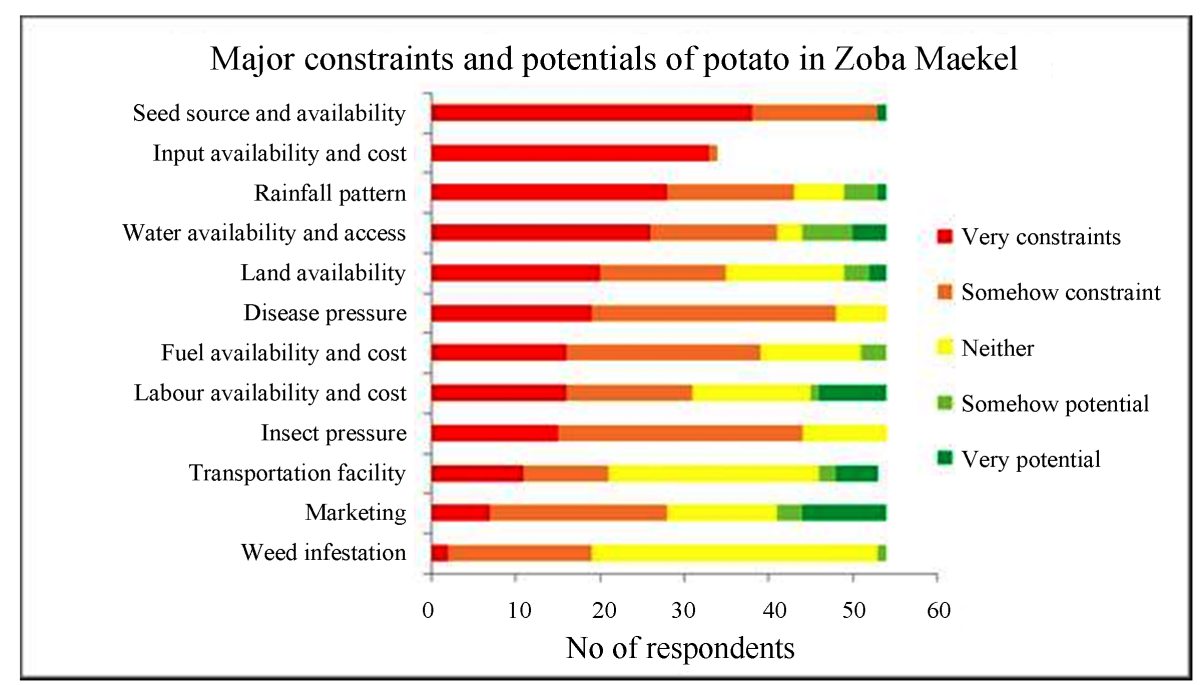

Figure 4. Major constraints and potentials of potato cultivation in Eritrea, Zoba Maekel.

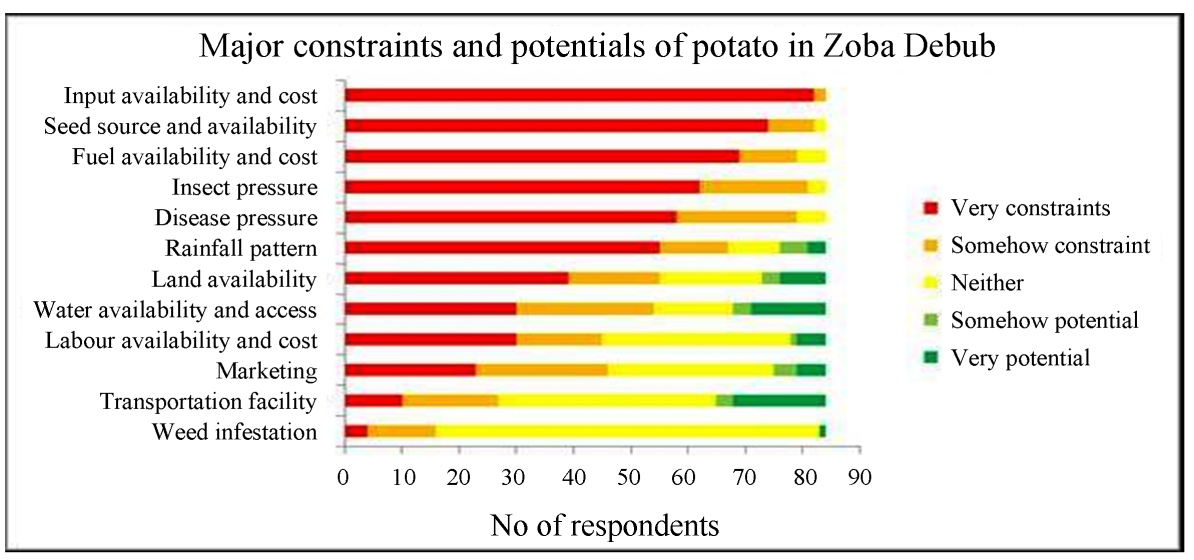

Figure 5. Major constraints and potentials of potato cultivation in Eritrea, Zoba Debub.

was noted from the survey that there is no established and sustainable clean seed supply system in the country resulting in informal and poor quality seed marketing which caused illegal low quality seed importation believed to increase disease spread and mix up of varieties. Most of the subsistent farmers are required to save their own seed for the next cycle. Tsaeda embaba is a local variety widely and commonly grown variety owing to its yield and resistance to biotic and abiotic stress. According to, [7] it was reported that using quality seed with improved technology will help farmers optimize their produce. Although farmers follow different methods to identify their preferred varieties but majority relies on the tuber shape, tuber color and leaf shape in the farm. Accordingly majority (76.1\%) of the respondents prefer round shaped and white coloured variety. Moreover, maturity time, yield, taste and marketability are among the most common criteria for variety preference. The current study further revealed that the most common marketing out lets are wholesale, retailer and with limited amount to direct consumers. Growers divide their produce in to three classes as large ones for market, middle for seed and small for home consumption. The study further identified the major constraints and potentials of potato cultivation in Eritrea. Although the degree and level varies from Zoba to Zoba, but generally it was noted that lack of agricultural inputs such as pesticides, fertilizers, application equipment, availability and cost of clean seeds are some of the constraints limiting productivity. On the other hand, transportation access and market demand are considered to be potentials encouraging growers. From the current study it is recommended that a standard and sustainable quality seed supply system should be established on top of providing necessary agricultural inputs at a reasonable price and in time to increase productivity. An extension service on the wise use of resources and marketing exercises, advising growers to form farmers' cooperatives will empower poor and subsistent far- 
mers to play role in determining market prices.

\section{Acknowledgements}

We would like to acknowledge the Japanese International Cooperation Agency (JICA) for funding this research in collaboration with the Eritrean National Board for Higher Education (NBHE).

\section{References}

[1] Hamideldin, N. and Hussien, O.S. (2013) Morphological, Physiological and Molecular Changes in Solanumtuberosum L. in Response to Pre-Sowing Tuber Irradiation by Gamma Rays. American Journal of food science and Technology, 1, 36-41.

[2] Kaguongo, W.P., Gildemacher, P., Demo, P., Wagoire, W., Kinyae, P., Andrade, J., Forbes, G., Fuglie, K. and Thiele, G. (2008) Framer Practices and Adoption of Improved Potato Varieties in Kenya and Uganda. International Potato Center (CIP), Lima. SOCIAL Sciences Working Paper 2008-5, 85 p.

[3] Poczai, P., Cernák, I., Gorji, A.M., Nagy, S., Taller, J. and Polgár, Z. (2010) Development of Intron Targeting (IT) Markers for Potato and Cross-Species Amplification in Solanum nigrum (Solanaceae). American Journal of Botany, 97, e142-e145. http://intl.amjbot.org/ http://dx.doi.org/10.3732/ajb.1000360

[4] Sneyers, G. (2010) Potato and Commodity Development. In: Cromme, N., Prakash, A.B., Lutaladio, N.B. and Ezeta, F., Eds., Strengthening Potato Value Chains: Technical and Policy Options for Developing Countries, The Food and Agriculture Organization of the United Nations and the Common Fund for Commodities, Rome, 12-13.

[5] Khan, M.A. (2010) Potential Markets of Potato. Trade Development Authority of Pakistan, Karachi.

[6] Badoni, A. and Chauhan, J.S. (2009) Microtuber: A Source of Germplasm Conservation. Report and Option, 1, 69-71.

[7] Prakash, A.B. (2010) Introduction: The Role of Potato in Developing Country Food Systems. In: Cromme, N., Prakash, A.B., Lutaladio, N.B. and Ezeta, F., Eds., Strengthening Potato Value Chains: Technical and Policy Options for Developing Countries, The Food and Agriculture Organization of the United Nations and the Common Fund for Commodities, Rome, 14-24.

[8] Lemaga, B. (2010) The Potato Value Chain in Sub-Saharan Africa with Case Study on Eastern Africa. In: Cromme, N., Prakash, A.B., Lutaladio, N.B. and Ezeta, F., Eds., Strengthening Potato Value Chains: Technical and Policy Options for Developing Countries, The Food and Agriculture Organization of the United Nations and the Common Fund for Commodities, Rome, 43-54.

[9] CIP (2011) Roadmap for Investment in the Seed Potato Value Chain in Eastern Africa. International Potato Center (CIP), Lima.

[10] Gildemacher, P.R. (2012) Innovation in Seed Potato Systems in Eastern Africa. PhD Thesis, Wageningen University, Wageningen.

[11] Pandey, S.K. (2009) Potato Research Priorities in Asia and the Pacific Region. In: Papademetriou, M.K., Ed., Proceedings of the Workshop to Commemorate the International Year of Potato-2008, Food and Agriculture Organization of the United Nations, Regional Office for Asia and the Pacific, Bangkok, 30-39.

[12] Gaur, P. (2010) Constraints of Potato Seed Production in Developing Countries. In: Cromme, N. Prakash, A.B., Lutaladio, N.B. and Ezeta, F., Eds., Strengthening Potato Value Chains: Technical and Policy Options for Developing Countries, The Food and Agriculture Organization of the United Nations and the Common Fund for Commodities, Rome, 61-70.

[13] Muthoni, J., Shimelis, H. and Melis, R. (2013) Potato Production in Kenya: Farming Systems and Production Constraints. Journal of Agricultural Science, 5, 182-197.

[14] Kadian, M.S., Lotha, N.E., Girish, B.H, Ilangantileke, S., Ortiz, O., Sah, U., Kumar, S., Pandey, S.K and Dkhor, S.A (2010) Baseline Study on Potato Seed Production Systems in Meghalaya and Nagaland States of Northeast India. International Potato Center (CIP), Lima, Working Paper-2, 21.

[15] Barrera, V. and Norton, G.W. (1999) Farmer Practices for Managing the Principal Potato Pests in the Province of Carchi, Ecuador: Results of a Baseline Survey and Participatory Appraisal. IPM CRSP Working Paper 99-1, Virginia Tech Blacksburg, 24061-0334.

[16] Janssens, S.R.M., Smit, A.B. and Buurma, J.S. (2004) Organic Potato Production Systems Organic Potato Growing and Late Blight in Seven European Countries: Production, Market and Legislation. In: Tamm, L., Smit, A.B., Hospers, M., Janssens, S.R.M., Buurma, J.S., Mølgaard, J.-P., Lærke, P.E., Hansen, H.H., Hermans, A., Bødker, L., Bertrand, C., Lambion, J., Finckh, M.R., Schüler, Chr., Lammerts, van Bueren E., Ruissen, T., Nielsen, B.J., Solberg, S., Speiser, B., Wolfe, M.S., Phillips, S., Wilcoxon, S.J. and Leifert, C., Eds., Assessment of the Socio-Economic Impact of Late Blight 
and State-of-the-Art Management in European, Research Institute of Organic Agriculture FiBL/Forschungs Institutfür Biologischen Landbau (FiBL), Frick, 11-29.

[17] Kyamanywa, S., Kashaija, I., Getu, E., Amata, R., Senkesha, N. and Kullaya, A. (2011) Enhancing Food Security through Improved Seed Systems of Appropriate Varieties of Cassava, Potato and Sweet Potato Resilient to Climate Change in Eastern Africa. ILRI, Nairobi.

[18] Tesfaye, A., Lemaga, B., Mwakasendo, J.A., Nzohabonayoz, Z., Mutware, J., Wanda, K.Y., Kinyae, P.M., Ortiz, O., Crissman, C. and Thiele, G. (2010) Markets for Fresh and Frozen Potato Chips in the ASARECA Region and the Potential for Regional Trade: Ethiopia, Tanzania, Rwanda, Kenya, Burundi and Uganda. Working Paper-1, International Potato Center (CIP), Lima, 44 p.

[19] Diallo, A. (2010) The Potato Value Chain in West Africa. In: Cromme, N. Prakash, A.B., Lutaladio, N.B. and Ezeta, F. Eds., Strengthening Potato Value Chains: Technical and Policy Options for Developing Countries, The Food and Agriculture Organization of the United Nations and the Common Fund for Commodities, Rome, 33-42. 
Scientific Research Publishing (SCIRP) is one of the largest Open Access journal publishers. It is currently publishing more than 200 open access, online, peer-reviewed journals covering a wide range of academic disciplines. SCIRP serves the worldwide academic communities and contributes to the progress and application of science with its publication.

Other selected journals from SCIRP are listed as below. Submit your manuscript to us via either submit@scirp.org or Online Submission Portal.
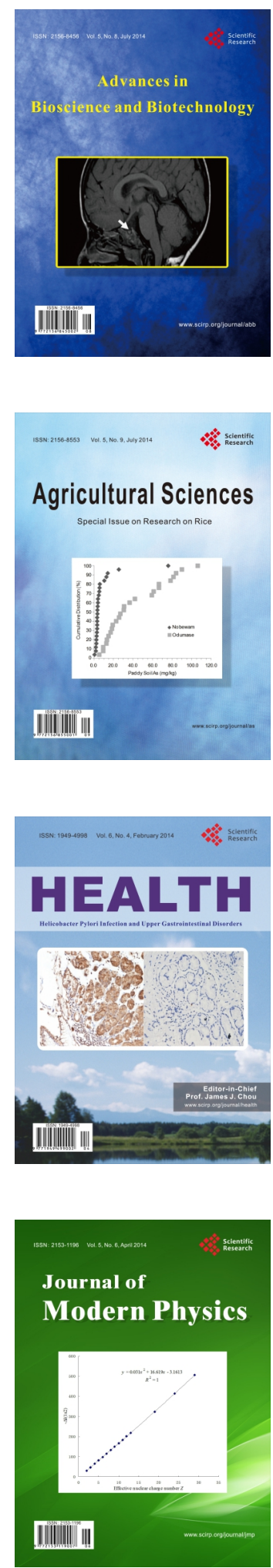
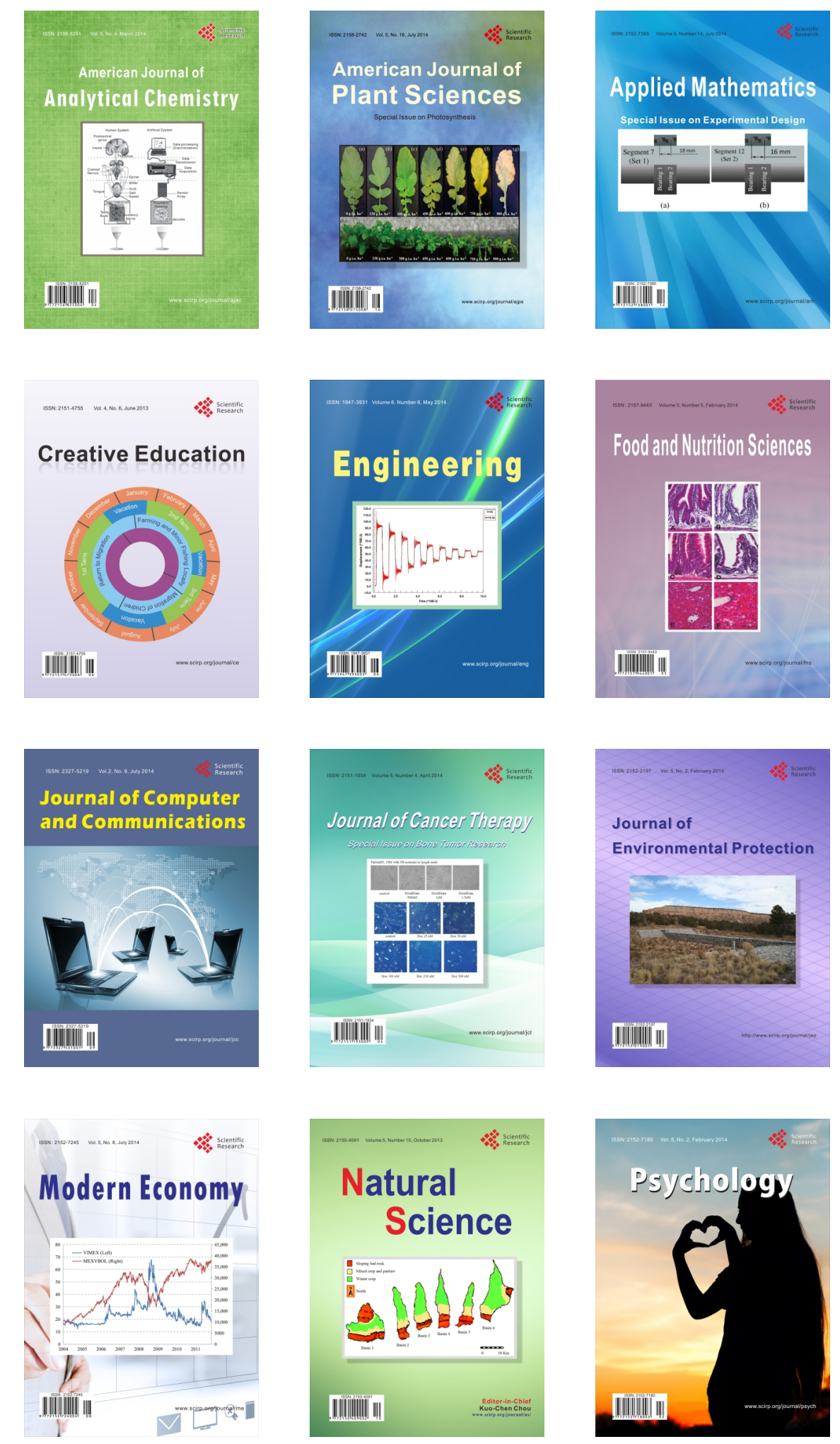